\title{
Dynamics of human facial aging through photoanthropometric analysis and quadratic modeling from child- to adulthood $-\mathrm{a}$ multi-centric study
}

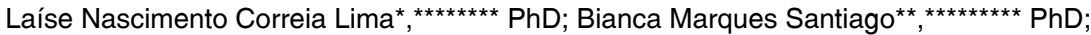 \\ Ademir Franco***, ${ }^{* \star *}$ PhD; Patrick Thevissen ${ }^{* \star * *}$ PhD; Flávio de Barros Vidal ${ }^{* \star \star *}$ PhD; \\ Lucas Faria Porto ${ }^{\star * \star \star *}$ MSc; Inmaculada Aleman Aguilera ${ }^{\star \star * \star * *}$ PhD;

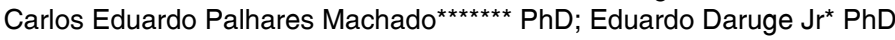

\section{Abstract}

This study aimed to investigate the dynamics of facial aging from photographs of individuals in different age groups and establish a pattern of facial growth. The sample consisted of digital photographs standardly taken from 1273 Brazilians aged between 2 and 24 years and equally distributed by sex into 12 specific age groups $(2,4,6,8,10,12,14,16,18,20,22$ and 24 years). SAFF-2D ${ }^{\circledR}$ (Forensic Facial Analysis System, Brazilian Federal Police, Brazil) software package was used for positioning 28 landmarks on each photograph. Twohundred and eight measurements were established between the landmarks. Photoanthropometric Indicators (PAI) of facial morphological alterations were obtained from the relations of facial measurements with a fixed reference (diameter of the iris). Non-transformed linear, quadratic and log-linear models were tested to screen the best approach to describe the facial growth with aging in females and males. The quadratic model reached the best outcomes in females $\left(R^{2}\right.$ $<73.2 \%$, mean: $52.14 \% \pm 0.15)$ and males $\left(\mathrm{R}^{2}<80.8 \%\right.$, mean: $\left.60.87 \% \pm 0.15\right)$. Most of the PAI (>99.04\%) were statistically associated with age in females and males $(p<0.05)$. Vertical facial alterations were

* Departamento de Odontologia Legal, Faculdade de Odontologia de Piracicaba, Universidade Estadual de Campinas, Av. Limeira 901, 13.414-903, Piracicaba, Brasil

** Departamento de Odontologia Clínica e Social, Universidade Federal da Paraíba. Campus I, Cidade Universitária, 58.051-900, João Pessoa, Brasil.

**** Department of Imaging and Pathology, Forensic Odontology, KU Leuven. Kapucijnenvoer 7, block B, 3000, Leuven, Belgium.

Division of Oral Radiology, Faculdade São Leopoldo Mandic, Instituto de Pesquisas São Leopoldo Mandic, Rua José Rocha Junqueira 13, 13.045-755, Campinas, Brasil.

****** Departamento de Ciências da Computação, Universidade de Brasília. Campus Darcy Ribeiro, Asa Norte, 70.910-900, Brasília, Brasil.

Departamento de Medicina Legal, Toxicología y Antropología Física, Universidad de Granada, Spain. Av. de la Investigación 11, 18.016, Granada, España.

Instituto Nacional de Criminalística, Polícia Federal Brasileira. Setor Policial, Quadra 7, Lote 23, Asa Sul, 70.610-200, Brasília, Brasil.

Departamento de Odontologia, Universidade Federal do Maranhão. Av. dos Portugueses s/n, Bacanga, 65.080-805, São Luiz, Brasil.

Departamento de Medicina e Odontologia Legal, Polícia Científica da Paraíba. R. Rua Antônio Teotônio s/n, Cristo Redentor, 58.071-620, João Pessoa, Brasil.

फhttp://dx.doi.org//10.5335/rbceh.v17i1.9888 
the most evident over the time, especially the height of the human face $(p<0.05)$. Data extraction and treatment performed with the photoanthropometric analysis and the quadratic statistical model described the dynamics of human facial growth aging from child- to adulthood. These outcomes may support clinicians in treatment planning and follow-up of interventions that prevent and intercept changes in the human face.

Keywords: Aging; Anatomy; Anthropology; Forensic medicine; Forensic dentistry

\section{Introduction}

Studies in facial growth and anatomy are fundamental to support optimal performances in health (RAFAI et al., 2016) and forensic sciences (LINDSAY, RÜHLI, DELEON, 2015; ERICKSON et al., 2017). In the first, knowledge of the facial morphological structures is necessary to guide maxillofacial surgeries (e.g. orthognatic surgery, cleft lip and palate reconstructions, and traumatology) and orthodontic treatment (e.g. prediction of development) (BISHARA, 2000). In the second, simulations of facial age progression may be performed to support criminal investigations on kidnapping, illegal adoption and sexual abuse (ENLOW, 1990; LAMPINEN et al., 2012; ZENG; MA; ZHOU, 2019)

Facial morphology considerably changes from child to adulthood (ENLOW, 1990; TAYLOR, 2000; WILKINSON; RYNN, 2012; XU et al., 2019) in a dynamic and continuous process guided by timing (ENLOW, 1990; RICANEK; BOONE,
2005; SCANDRETT; SOLOMON; GIBSON, 2006; RIGHI; PEISSIG; TARR, 2012; ERICKSON et al., 2017). In this process, the human face does not change uniformly (ENLOW, 1990; TURK; PENTLAND, 1991; VALENTINE, 2001; RICANEK; BOONE, 2005; KOUDELOVA et al., 2015). In practice, the complex allometric development of the face requires scientific strategies to study and understand the morphological changes with aging (MOREVITZ; COLLS, 2016).

Several methods are available to simulate facial aging. Many of them are founded on photographic references and on expert's knowledge of craniofacial development (TAYLOR, 2000 ; WILKINSON; RYNN, 2012; MOREVITZ; COLLS, 2016). The last is based on typical anthropometric models from the development of children and adolescents throughout age (ENLOW, 1990). These models may be applied in practice to update the known contemporary photograph of a person and to predict the inherent facial alterations in the future (TAYLOR, 2000). For more accurate performances in practice, the available methods proposed in the literature must be scientifically validated and new methods must be designed (CHARMAN; CAROL, 2012; ENLOW, 1990; FLORES; MACHADO, 2017).

In this scenario, photoanthropometry emerges as a promising method for the study of facial anatomy. This method consists in the bidimensional analysis of measurements, angles and proportions of human anthropological features from photographs guided by 
anatomically positioned landmarks (DAVIS; VALENTINE; DAVIS, 2010; ISÇAN; HELMER, 1993; KLEINBERG; VANEZIS; BURTON, 2007; MORETON; MORLEY, 2011). As most of the facial photographs are usually taken without scales, the photoanthropometric analysis may be performed by associating the ratio of two measurements and their unification in a single index (BORGES et al., 2018; FLORES et al., 2019; MACHADO et al., 2017). Despite the potential usefulness of photoanthropometry in anatomy highlighted by previous studies (CATTANEO et al., 2009; CATTANEO et al., 2012; RATNAYAKE et al., 2014; TEMPORINI, 2012), the scientific literature is scarce of population-based investigations and protocols to quantify facial age progression.

This study aimed to assess facial development in Brazilian individuals through photoanthropometric analysis and to establish a morphological growth pattern as reference for estimating the development of the different anatomic structures of the human face in function of age.

\section{Material and methods}

\section{Study design and ethical aspects}

An observational cross-sectional study was designed according to the checklist described in "Strengthening the Reporting of Observational Studies in Epidemiology" (STROBE) guidelines (VON ELM et al., 2008). The study was conducted after the approval of the university Committee of Ethics in Human Research - under the protocol number: 17017213.0.0000.5440.

\section{Settings and participants}

The data sample consisted of 1273 digital photographs from Caucasian Brazilians aged between 2 and 24 years. This age interval includes children and subadults up to the limit of young adulthood - covering the period of remarkable changes in the human face from a progressive aging process. The rationale behind this strategy aimed to deliver outcomes that are more applicable to practice (e.g. preventive orthopedic treatment and corrective surgical approach). The images were randomly and retrospectively collected from a national police database as an expanded sample of a previous study (MACHADO et al., 2017). Image acquisition was performed in frontal view following the protocol of the International Civil Aviation Organization (ICAO), which establishes a face-camera distance of 1.5 meters and the use of standard camera, lenses and flash (BICALHO et $a l ., 2018)$. The obtained images were stored in .png format, 24-bit per pixel and $640 \times 480$ pixels spatial resolution. The photographs were homogeneously distributed by sex into 12 age groups ( 2 , $4,6,8,10,12,14,16,18,20,22$ and 24 , \pm 1 month). Each of the age groups was composed by at least 50 photographs of males and 50 of females.

The inclusion criteria consisted of Brazilians within the age range of 2-24 
years, with neutral facial expression, closed lips and face positioned directly towards the camera. The exclusion criteria consisted of individuals with evident head rotation in the sagittal, axial or coronal planes; as well individuals with evident facial deformities, asymmetries, facial hair, jewelry, make up or those with incomplete photographic registration of the face.

\section{Data measurements and quantitative variables}

The anthropometric analysis was performed by placing 28 pre-established anatomic landmarks on the human face (Table 1, Figure 1). The landmarks were placed by 10 examiners previously trained and experienced in the field. Landmark placing was feasible with SAFF-2D ${ }^{\circledR}$ (Forensic Facial Analysis System, Brazilian Federal Police, Brazil) software package, which digitally registered the landmarks as Cartesian coordinates in $\mathrm{x}$ - and $\mathrm{y}$-axes, and horizontal and vertical axes, respectively. Two-hundred and eight measurements were obtained between each landmark. In case of bilateral measurements, the mean value between the left and right sides was considered (Figure 2).

Table 1: Description of the cephalometric landmarks used in this study

\begin{tabular}{|c|c|}
\hline Landmark & Description \\
\hline 1. Nasion (n) & $\begin{array}{l}\text { The interception of the midsagittal plane and the line crossing the superior palpebral } \\
\text { creases }\end{array}$ \\
\hline 2. Subnasale (sn) & The lowest point of the nose on the midsagittal plane \\
\hline 3. Gnathion (gn) & The lowest point of the chin, on the midsagittal plane \\
\hline 4. Endocanthion (en) & The medial limit of the eye \\
\hline 5. Ectocanthion (ec) & The lateral limit of the eye \\
\hline 6. Iridion laterale (il) & The most lateral point of the rim of the iris \\
\hline 7. Iridion mediale (im) & The most medial point of the rim of the iris \\
\hline 8. Pupil (pu) & $\begin{array}{l}\text { The central point of the iris, mathematically calculated, between the Iridion laterale } \\
\text { and the Iridion mediale of each eye }\end{array}$ \\
\hline 9. Zygion (zy) & The widest point in the region of the zygomatic bone seen in the frontal view \\
\hline 10. Chelion (ch) & The lateral limit of the mouth \\
\hline 11. Alare (al) & The most lateral point on the "wing" of the nose \\
\hline 12. Glabella (g) & Most anterior midline point on the forehead, in the region of the superciliary ridges \\
\hline 13. Labiale superius (Is) & Midpoint of the vermilion border of the upper lip \\
\hline 14. Stomion (sto) & $\begin{array}{l}\text { Midline point of the labial fissure when the lips are closed naturally, with teeth shut } \\
\text { in the natural position }\end{array}$ \\
\hline 15. Labiale inferius (li) & Midpoint of the vermilion border of the lower lip \\
\hline 16. Midnasal (mid) & Median point at the between the endocanthion points \\
\hline 17. Gonion (go) & Most lateral point on the mandibular angle \\
\hline 18. Crista philtri (cph) & Point on each elevated margin of the philtrum just before projection to the vermilion line \\
\hline
\end{tabular}


Figure 1: Landmarks adopted in this study

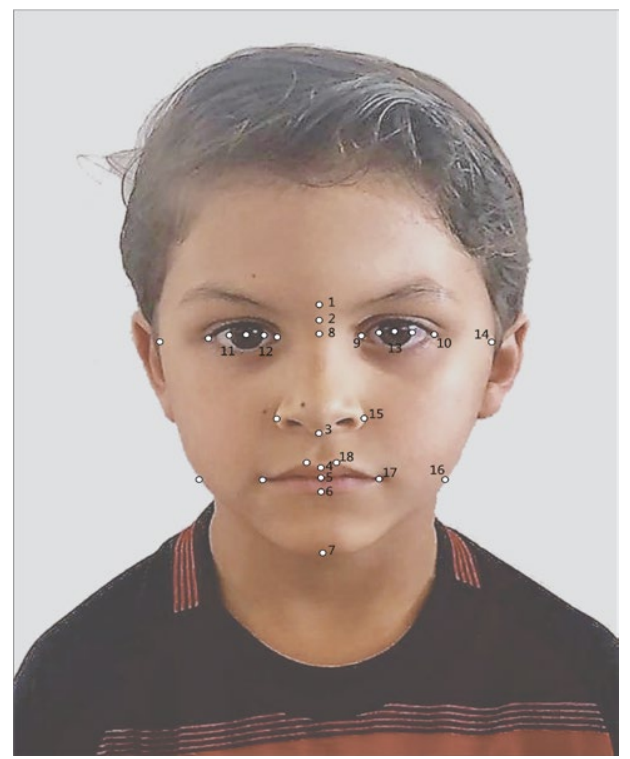

Legend: 1 . Glabella (g); 2. Nasion (n); 3. Subnasale (sn); 4. Labiale superius (ls); 5. Stomion (sto); 6. Labiale inferius (li); 7. Gnathion (gn); 8. Midnasal Ec (mid); 9. Entocanthion (en); 10. Exocanthion (ec); 11. Iridion laterale (il); 12. Iridion mediale (im); 13. Pupil (pu); 14. Zygion (zy); 15. Alare (al); 16. Gonion (go); 17. Cheilion (ch); 18. Crista philtri (cph). Morphological descriptions of these landmarks are found in Table 1.

Figure 2-Facial measurements calculated from frontal photographs using single (A) and bilateral landmarks (B)

A

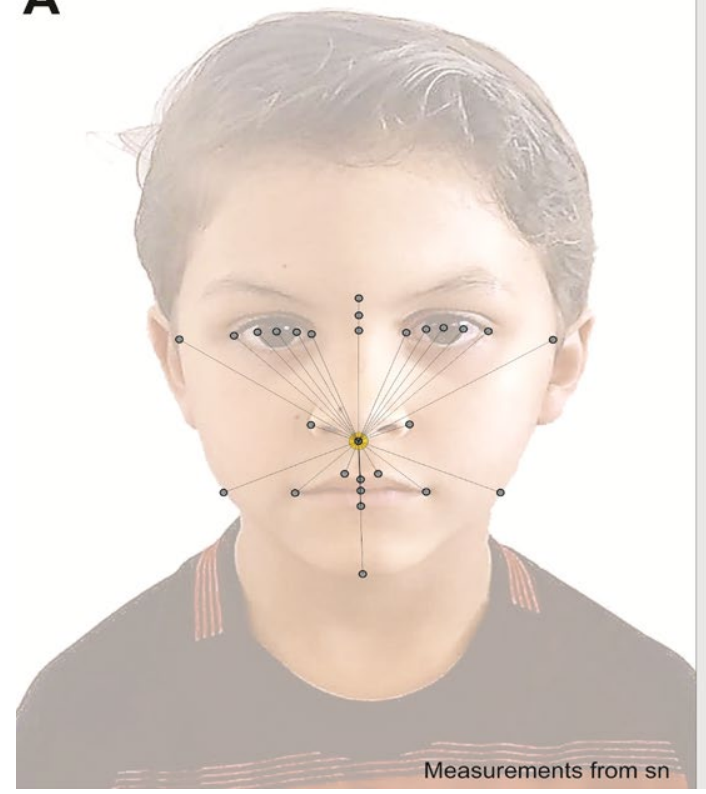

B

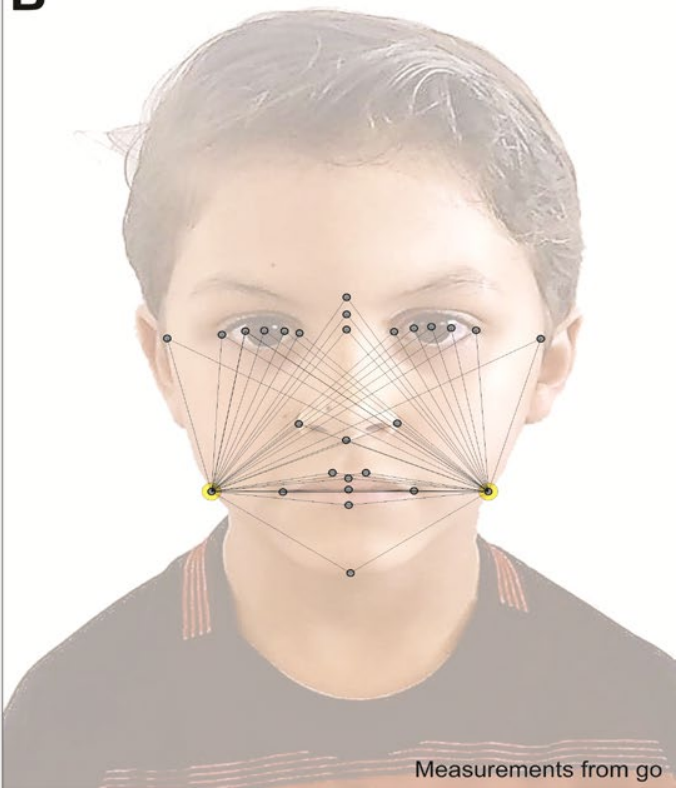

Legend: Measurements calculated from the subnasale (sn) and gonion (go) landmarks 
For the analysis of facial growth, specific Photoanthropometric Indicators (PAI) were calculated from the relation of each facial measurement and the diameter of the iris. This procedure enabled the analysis of facial growth as function of age using the diameter of the iris as the most stable calibration reference in the human face (MACHADO et al., 2017).

\section{Assessment of examiner bias}

Intra- and inter-examiner bias was assessed by randomly selecting 10 photographs and providing them for landmark placement. This subsample was analyzed three times by each of the examiners within an interval of 15 days between the analyses. The reproducibility between examiners was expressed within the Intraclass Correlation Coefficient.

\section{Statistical methods}

PAI descriptive statistics was registered for each age group and sex. Mann-Whitney test was used to compare the mean PAIs between males and females. Linear, quadratic and log-linear statistical models were designed to investigate the progressive alterations of the PAIs with age. $\mathrm{R}^{2}$ and Akaike Information Criterion were considered for choosing a single model that better described the facial development (YANG, 2005).
Additionally, the PAIs were investigated separately based on their contribution to the quadratic statistical model. Next, they were ranked based on their metric variability according to sex. Statistical analyses were performed with $\mathrm{R}$ (The $\mathrm{R}$ Foundation, Vienna, Austria) software package with significance level set at $5 \%$ and confidence interval of $95 \%$.

Additionally, diagrams of the face were designed using the PAIs in order to represent the facial growth in relation to the regression curves obtained from the best statistical model. Figure 3 shows ten measurements that better illustrate the human face and its variation over the time were chosen, six of them were related to horizontal distances (facial width) and four to vertical distances (facial height). The Midnasal (mid) landmark was used in replacement of Glabella (g) and Nasion (n) as a fixed point in y axis (anchor point) because it was easier to locate in frontal images of the face. In order to design the diagrams of the face, standard photographs of females and males at the age of 2 years were used as baseline. From the baseline, cumulative percentages of growth within intervals of two years were multiplied - generating diagrams separately for females and males. 
Figure 3 - Measurements taken from the human face to enable the simulation of age progression with cumulative growth

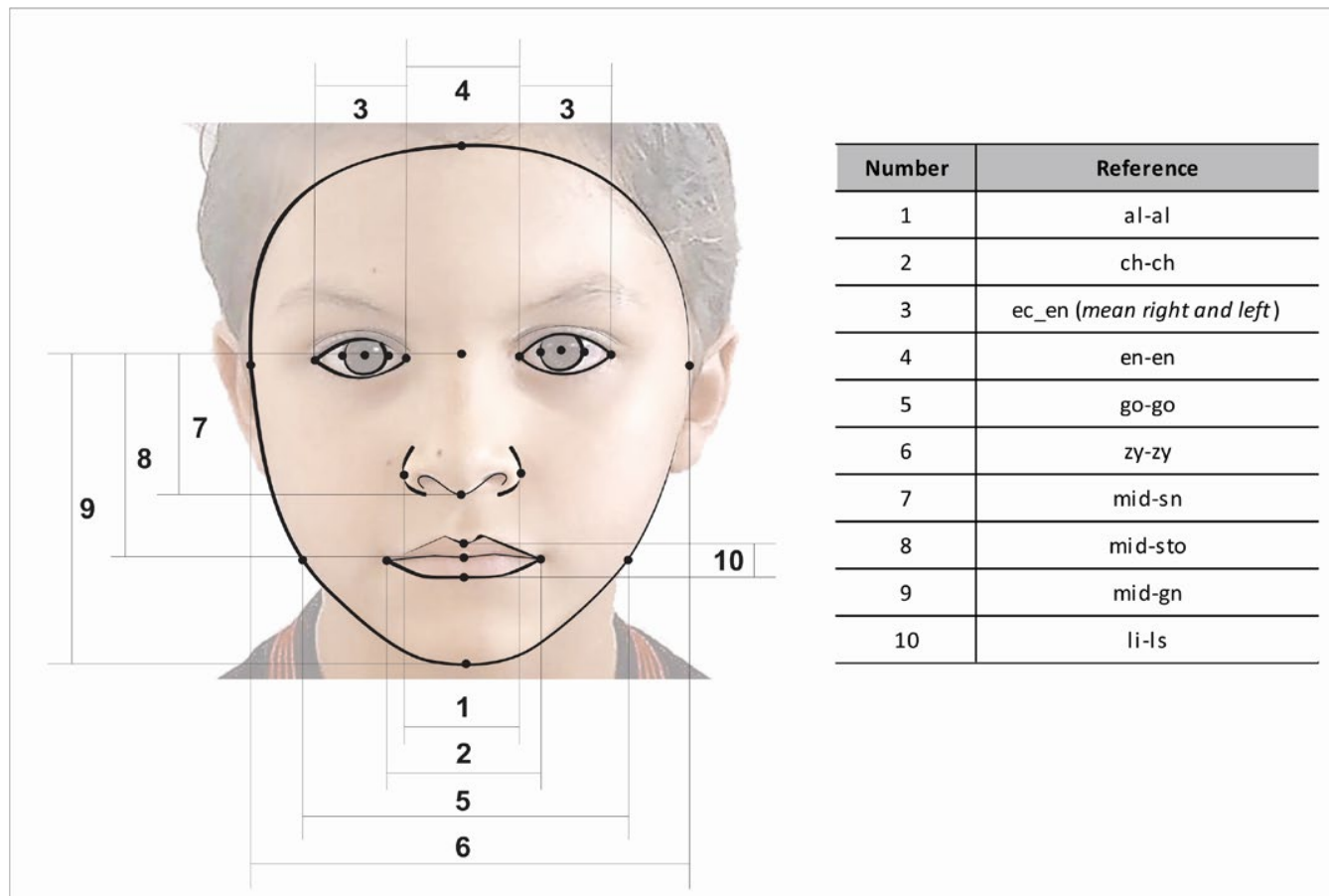

Legend: Four measurements were taken vertically and six were taken horizontally

\section{Results}

Intraclass Correlation Coefficient outcomes showed excellent intra- and inter-examiner reproducibility $(>0.90$, $\mathrm{p}<0.001$ ).

The quadratic model figured as the best fit for describing the variations of the PAIs according to age, and sex. In females, the quadratic model reached $\mathrm{R}^{2}$ values that ranged from $0.2 \% \mathrm{tc}$
$72.3 \%$ (mean: $52.14 \% \pm 0.15$ ), while the Akaike Information Criterion ranged from -39227.9 to 1399.84 (mean: -0.76 \pm 2819.93 ). In males, the $R^{2}$ values with the same model ranged from $0.1 \%$ to 80.8\% (mean: $60.87 \% \pm 0.15$ ), while the AIC values ranged from -38772.6 to 1450.17 (mean: $139.84 \pm 2779.56$ ) (Table 2). 
Table 2: Quality indicators of the three statistic models designed to describe facial growth in function of age distributed according to sex

\begin{tabular}{l|r|r|r|r|r|r}
\hline \multirow{2}{*}{ Quality indicators } & \multicolumn{3}{|c|}{ Females } & \multicolumn{3}{c}{ Males } \\
\cline { 2 - 7 } & Model 1 & Model 2 & Model 3 & Model 1 & Model 2 & Model 3 \\
\hline $\mathrm{R}^{2}$ min. (\%) & 0.1 & 0.2 & 0.1 & 0 & 0.1 & 0 \\
$\mathrm{R}^{2}$ max. (\%) & 60.6 & 73.2 & 58.5 & 78 & 80.8 & 76.2 \\
Mean R (\%) & 41.49 & 52.14 & 40.27 & 58.53 & 60.87 & 57.48 \\
Standard deviation & 12.99 & 0.15 & 0.12 & 0.15 & 0.15 & 0.15 \\
Median R² (\%) & 44 & 55 & 42 & 62 & 64 & 61 \\
AIC min. & -39226.7 & -39227.9 & -3939.7 & -38771.8 & -38772.6 & -41785 \\
AIC max. & 1443.73 & 1399.84 & 1449.42 & 1452.57 & 1450.17 & 1455.76 \\
Mean AIC & 140.80 & -0.76 & 549.31 & 181.19 & 139.84 & 186.14 \\
Standard deviation & 2837.35 & 2819.93 & 3022.01 & 2784.71 & 2779.56 & 2990.65 \\
Median AIC & 555.66 & 373.94 & 576.96 & 562.56 & 513.32 & 576.5 \\
\hline
\end{tabular}

$\mathrm{R}^{2}$ : Coefficient of determination; AIC: Akaike Information Criterion; Model 1: linear; Model 2: quadratic; Model 3: log-linear. $\mathrm{R}^{2}$ and AIC values express the quality of each model for males and females. The first is directly proportional - the higher the value the better the model, while the second is the opposite - the lower the value the better the model.

PAI values were defined using the formula: $P A I=\beta$ Intercept $+($ real age $\times \beta$ age $)+\left(\right.$ real age $^{2} \times \beta$ age $\left.^{2}\right)$. As an example, for a 10-year-old female, the value of PAI115, as shown in table 3, would be: PAI115 $=7.055+(10 \times 0.363)+\left(10^{2} \times\right.$ $(-0.009))$. In this case, PAI $115=9.785$.

In females and males, all the PAI showed statistically significant behavior with aging $(p<0.05)$, except for the distances between the lateral (PAI 160) and medial (PAI 171) surface of the iris to the pupil in both sexes, and the distance from nasion to midnasal (PAI190) for males $(p>0.05)$. Table 3 and figure 4 revealed that, in general, the height of the human face (PAI 115) figured as the PAI with highest alteration with age in the overall sample $(\mathrm{p}<0.05)$.

Table 3: Behavior of the photoanthropometric indicator (PAI) that showed the highest alteration in function of age in females and males

\begin{tabular}{l|l|c|c|c|c|c|c|c|c}
\hline \multirow{2}{*}{ PAI } & \multirow{2}{*}{ Factor } & \multicolumn{5}{|c|}{ Females } & \multicolumn{4}{c}{ Males } \\
\cline { 3 - 9 } & & $\beta$ & $\mathrm{SE}$ & $\mathrm{Cl}(95 \%)$ & $\mathrm{p}$ & $\beta$ & $\mathrm{SE}$ & $\mathrm{Cl95 \%}$ & $\mathrm{p}$ \\
\hline \multirow{3}{*}{115} & Intercept & 7.055 & 0.081 & {$[6.896 ; 7.215]$} & 0.000 & 6.947 & 0.091 & {$[6.770 ; 7.125]$} & 0.000 \\
& Age & 0.363 & 0.014 & {$[0.335 ; 0.391]$} & 0.000 & 0.337 & 0.016 & {$[0.305 ; 0.368]$} & 0.000 \\
& Age & -0.009 & 0.001 & {$[-0.01 ;-0.008]$} & 0.000 & -0.006 & 0.001 & {$[-0.007 ;-0.005]$} & 0.000 \\
\hline
\end{tabular}

PAI: photoanthropometric indicators (the complete list with the description of each indicator may be available upon request); PAI 115: height of the face (showed more alterations with age); $\beta$ : value of the intercept, age and age ${ }^{2}$ in the quadratic equation from the statistical model; SE: standard error; CI: confidence interval range (95\%); p: p-value with statistical significance set at $5 \%$. 
Figure 4: Representation of the photoanthropometric indicator (PAI) with the highest alteration over the time in females and males

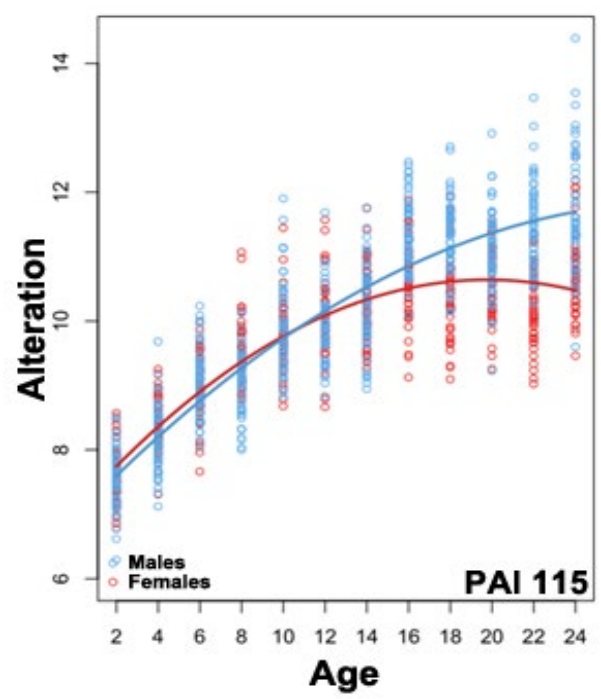

Legend: Height of the face (PAI 115) was the most altered PAI in function of age for females (red) and males (blue). This PAI is described as the relation between the distance of the landmarks glabella (g) and gnation (gn) in relation to the diameter of the iris.

In females, the five morphological measurements that had the most significant alterations were the height of the face (PAI 115: 0.363), followed by the distance from the chin to the medial surface of the iris (PAI 129: 0.334), the distance from the chin to the pupil (PAI 134: 0.332), the distance from the chin to the lateral surface of the iris (PAI 128: 0.330 ), and the distance from the chin to the ectocanthion (PAI 79: 0.329). According to table 4, in males, PAIs 115 (0.337), 129 $(0.315)$ and $134(0.311)$ repeated in the top, followed by the distance from the chin to the endocanthion (PAI 98: 0.307) and the distance from the chin to the latera] surface of the iris (PAI 128: 0.306).
Table 4: Top 5 photoanthropometric indicators (PAI) with the highest alterations with aging in females and males

\begin{tabular}{|c|c|c|c|c|c|c|}
\hline Sex & PAI & Factor & $\beta$ & SE & $\mathrm{Cl} 95 \%$ & $\mathrm{p}$ \\
\hline \multirow{15}{*}{$\mathrm{F}$} & \multirow{4}{*}{115} & Intercept & 7.055 & 0.081 & {$[6.896 ; 7.215]$} & 0.000 \\
\hline & & Age & 0.363 & 0.014 & {$[0.335 ; 0.391]$} & 0.000 \\
\hline & & $\mathrm{Age}^{2}$ & -0.009 & 0.001 & {$[-0.01 ;-0.008]$} & 0.000 \\
\hline & & Intercept & 6.302 & 0.077 & {$[6.152 ; 6.453]$} & 0.000 \\
\hline & \multirow[t]{3}{*}{129} & Age & 0.334 & 0.013 & {$[0.308 ; 0.36]$} & 0.000 \\
\hline & & $\mathrm{Age}^{2}$ & -0.009 & 0.001 & {$[-0.01 ;-0.008]$} & 0.000 \\
\hline & & Intercept & 6.441 & 0.076 & {$[6.291 ; 6.59]$} & 0.000 \\
\hline & \multirow[t]{3}{*}{134} & Age & 0.332 & 0.013 & {$[0.306 ; 0.359]$} & 0.000 \\
\hline & & $\mathrm{Age}^{2}$ & -0.008 & 0.000 & {$[-0.009 ;-0.007]$} & 0.000 \\
\hline & & Intercept & 6.612 & 0.076 & {$[6.463 ; 6.76]$} & 0.000 \\
\hline & \multirow[t]{3}{*}{128} & Age & 0.330 & 0.013 & {$[0.304 ; 0.356]$} & 0.000 \\
\hline & & $\mathrm{Age}^{2}$ & -0.008 & 0.000 & {$[-0.009 ;-0.007]$} & 0.000 \\
\hline & & Intercept & 6.709 & 0.075 & {$[6.563 ; 6.855]$} & 0.000 \\
\hline & \multirow[t]{2}{*}{79} & Age & 0.329 & 0.013 & {$[0.303 ; 0.355]$} & 0.000 \\
\hline & & $\mathrm{Age}^{2}$ & -0.008 & 0.000 & {$[-0.009 ;-0.007]$} & 0.000 \\
\hline \multirow{15}{*}{ M } & \multirow{4}{*}{115} & Intercept & 6.947 & 0.091 & {$[6.77 ; 7.125]$} & 0.000 \\
\hline & & Age & 0.337 & 0.016 & {$[0.305 ; 0.368]$} & 0.000 \\
\hline & & $\mathrm{Age}^{2}$ & -0.006 & 0.001 & {$[-0.007 ;-0.005]$} & 0.000 \\
\hline & & Intercept & 6.204 & 0.085 & {$[6.037 ; 6.372]$} & 0.000 \\
\hline & \multirow[t]{3}{*}{129} & Age & 0.315 & 0.015 & {$[0.285 ; 0.345]$} & 0.000 \\
\hline & & $\mathrm{Age}^{2}$ & -0.006 & 0.001 & {$[-0.007 ;-0.004]$} & 0.000 \\
\hline & & Intercept & 6.352 & 0.085 & {$[6.186 ; 6.517]$} & 0.000 \\
\hline & \multirow[t]{3}{*}{134} & Age & 0.311 & 0.015 & {$[0.281 ; 0.341]$} & 0.000 \\
\hline & & $\mathrm{Age}^{2}$ & -0.005 & 0.001 & {$[-0.007 ;-0.004]$} & 0.000 \\
\hline & & Intercept & 5.880 & 0.084 & {$[5.715 ; 6.045]$} & 0.000 \\
\hline & \multirow[t]{3}{*}{98} & Age & 0.307 & 0.015 & {$[0.278 ; 0.337]$} & 0.000 \\
\hline & & $\mathrm{Age}^{2}$ & -0.005 & 0.001 & {$[-0.007 ;-0.004]$} & 0.000 \\
\hline & & Intercept & 6.534 & 0.084 & {$[6.37 ; 6.698]$} & 0.000 \\
\hline & \multirow[t]{2}{*}{128} & Age & 0.306 & 0.015 & {$[0.277 ; 0.335]$} & 0.000 \\
\hline & & $\mathrm{Age}^{2}$ & -0.005 & 0.001 & {$[-0.006 ;-0.004]$} & 0.000 \\
\hline
\end{tabular}

F: females; M: males; PAI: photoanthropometric indicators (the complete list with the description of each indicator may be available upon request); PAI 115: height of the face; PAI 129: distance from the chin to the medial surface of the iris; PAI 134: distance from the chin to the pupil; PAI 128: distance from the chin to the lateral surface of the iris; PAI 79: distance from the chin to the ectocanthion; PAI 98: distance from the chin to the endocanthion; $\square$ : value of the intercept, age and age $^{2}$ in the quadratic equation from the statistical model; SE: standard error; CI: confidence interval range (95\%); p: p-value with statistical significance set at $5 \%$. 
Table 5 is provided as a tool for practical simulation of facial growth. Specifically, this table shows the cumulative and gradual growth of the ten most significant morphological measurements in females and males from 2 to 24 years of age. In females, the highest cumulative growth was observed in the height of the lips (PAI 177), which grew $77 \%$ from 2 to 24 years; while in males the distance from the midnasal to the gnathion landmarks (PAI 132) showed the highest growth rate: $60 \%$ from 2 to 24 years - illustrated in figure 5 .

Table 5: Top 10 morphological structures with the highest cumulative and gradual growth rates from 2- to 24-year-old females and females

\begin{tabular}{|c|c|c|c|c|c|c|c|c|c|c|c|c|c|}
\hline Sex & Al & 2 & 4 & 6 & 8 & 10 & 12 & 14 & 16 & 18 & 20 & 22 & 24 \\
\hline & 0 & 0 & $5(+5)$ & $9(+4)$ & $12(+3)$ & $15(+3)$ & $17(+2)$ & $19(+2)$ & $20(+1)$ & $20^{*}$ & 20 & 20 & 20 \\
\hline & 27 & 0 & $9(+9)$ & $17(+8)$ & $23(+6)$ & $29(+6)$ & $33(+4)$ & $36(+3)$ & $39(+3)$ & $40(+1)$ & $40^{*}$ & 40 & 40 \\
\hline & 76 & 0 & $5(+5)$ & $9(+4)$ & $12(+3)$ & $14(+2)$ & $16(+2)$ & $17(+1)$ & $17^{\star}$ & 17 & 17 & 17 & 17 \\
\hline & 96 & 0 & $4(+4)$ & $7(+3)$ & $10(+3)$ & $12(+2)$ & $14(+2)$ & $14^{*}$ & 14 & 12 & 14 & 14 & 14 \\
\hline & 138 & 0 & $4(+4)$ & $8(+4)$ & $11(+3)$ & $14(+3)$ & $16(+2)$ & $18(+2)$ & $19(+1)$ & $20(+1)$ & $20^{*}$ & 20 & 20 \\
\hline & 192 & 0 & $9(+9)$ & $17(+8)$ & $23(+6)$ & $28(+5)$ & $32(+4)$ & $35(+3)$ & $37(+2)$ & $37^{*}$ & 37 & 37 & 37 \\
\hline & 193 & 0 & $8(+8)$ & $14(+6)$ & $20(+6)$ & $24(+4)$ & $28(+4)$ & $30(+2)$ & $32(+2)$ & $33(+1)$ & $33^{*}$ & 33 & 33 \\
\hline & 132 & 0 & $8(+8)$ & $16(+8)$ & $22(+6)$ & $27(+5)$ & $32(+5)$ & $35(+3)$ & $38(+3)$ & $39(+1)$ & $40(+1)$ & $40^{*}$ & 40 \\
\hline & 177 & 0 & $11(+11)$ & $22(+11)$ & $31(+9)$ & $40(+9)$ & $48(+8)$ & $55(+7)$ & $61(+6)$ & $66(+5)$ & $71(+5)$ & $74(+3)$ & $77(+3)^{*}$ \\
\hline & 207 & 0 & $4(+4)$ & $7(+3)$ & $9(+2)$ & $12(+3)$ & $13(+1)$ & $15(+2)$ & $15^{\star}$ & 15 & 15 & 15 & 15 \\
\hline & 0 & 0 & $6(+6)$ & $12(+6)$ & $17(+5)$ & $23(+6)$ & $27(+4)$ & $32(+5)$ & $36(+4)$ & $40(+4)$ & $43(+3)$ & $46(+3)$ & $49(+3)^{\star}$ \\
\hline & 27 & 0 & $7(+7)$ & $13(+6)$ & $19(+6)$ & $25(+6)$ & $29(+4)$ & $34(+5)$ & $37(+3)$ & $40(+3)$ & $43(+3)$ & $45(+2)$ & $47(+2)^{*}$ \\
\hline & 76 & 0 & $3(+3)$ & $6(+3)$ & $8(+2)$ & $10(+2)$ & $11(+1)$ & $12(+1)$ & $13(+1)$ & $14(+1)$ & $14^{*}$ & 14 & 14 \\
\hline & 96 & 0 & $4(+4)$ & $8(+4)$ & $11(+3)$ & $14(+3)$ & $17(+3)$ & $20(+3)$ & $22(+2)$ & $23(+1)$ & $25(+2)$ & $26(+1)$ & $26^{*}$ \\
\hline & 138 & 0 & $5(+5)$ & $9(+4)$ & $13(+4)$ & $17(+4)$ & $21(+4)$ & $25(+4)$ & $28(+3)$ & $31(+3)$ & $34(+3)$ & $37(+3)$ & $39(+2)^{*}$ \\
\hline & 192 & 0 & $8(+8)$ & $16(+8)$ & $23(+7)$ & $29(+6)$ & $35(+6)$ & $40(+5)$ & $44(+4)$ & $48(+4)$ & $51(+3)$ & $54(+3)$ & $56(+2)^{*}$ \\
\hline & 193 & 0 & $7(+7)$ & $13(+6)$ & $19(+6)$ & $24(+5)$ & $28(+4)$ & $32(+4)$ & $35(+3)$ & $38(+3)$ & $40(+2)$ & $42(+2)$ & $43(+1)^{*}$ \\
\hline & 132 & 0 & $9(+9)$ & $16(+7)$ & $24(+8)$ & $30(+6)$ & $36(+6)$ & $42(+6)$ & $47(+5)$ & $51(+4)$ & $54(+3)$ & $57(+3)$ & $60(+3)^{*}$ \\
\hline & 177 & 0 & $14(+14)$ & $26(+12)$ & $36(+10)$ & $44(+8)$ & $51(+6)$ & $55(+4)$ & $58(+3)$ & $58^{*}$ & 58 & 58 & 58 \\
\hline & 207 & 0 & $3(+3)$ & $5(+2)$ & $8(+3)$ & $11(+3)$ & $13(+2)$ & $16(+3)$ & $18(+2)$ & $20(+2)$ & $22(+2)$ & $24(+2)$ & $26(+2)^{\star}$ \\
\hline
\end{tabular}

F: females; M: males; PAI: photoanthropometric indicators; Cumulative (out of parentheses) and within-two-years gradual (in parentheses) growth rates expressed in percentage values (\%); *: Facial structures signaling towards complete development. 
Figure 5: Diagrams of the cumulative facial growth in females and males

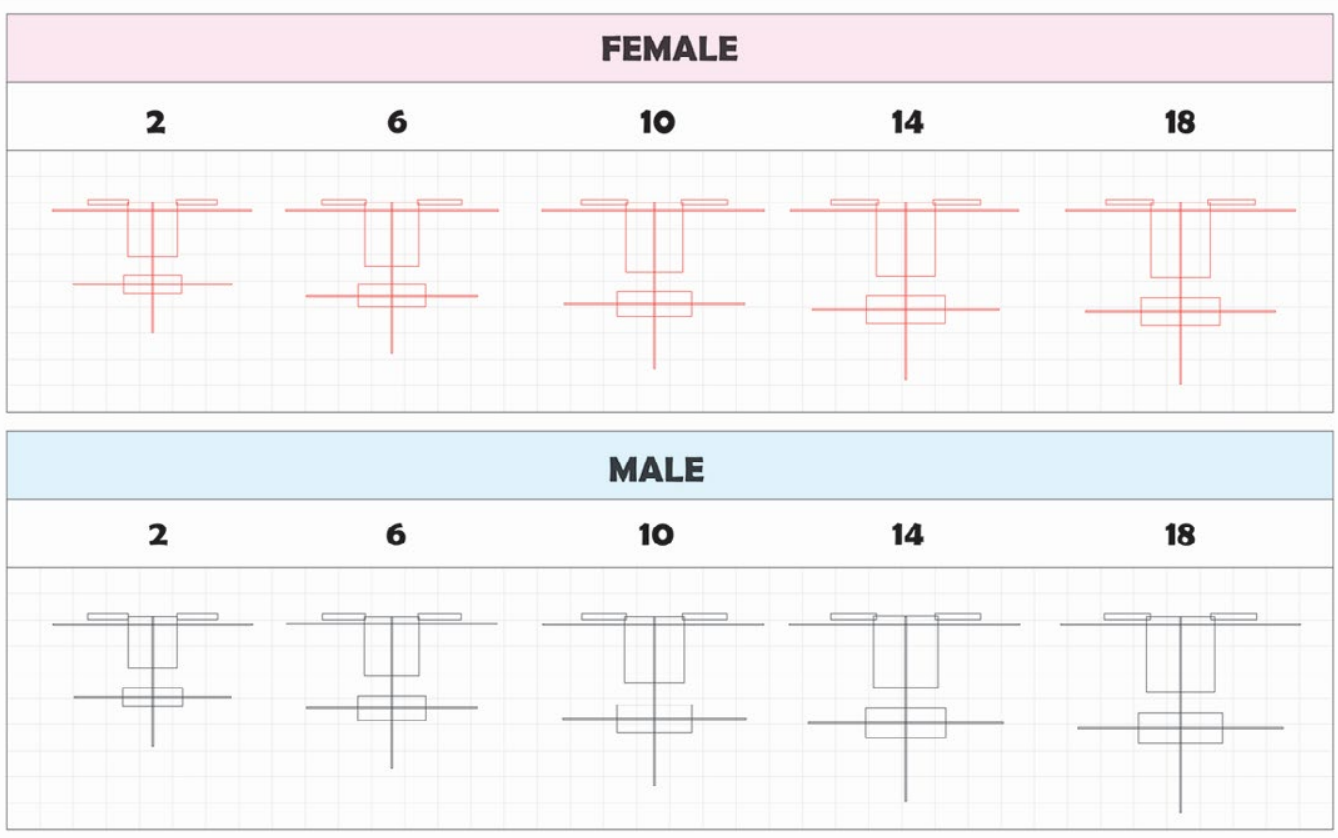

Legend: The diagrams of facial growth in females and males express the cumulative growth observed from 2 to 18 years within time intervals of 4 years. While the facial representations are realistic in the childhood and adolescence, non-realistic representations with a disproportional growth of the lower third of the face are shown around the age of 18 . This phenomenon is generated by limitations inherent to the quadratic modeling and raises a flag for caution on the application of quadratic models for studying the dynamics of human facial growth in subadults.

\section{Discussion}

Studies about human facial aging may be performed in many fields of science to understand the phenotypic expression of gene polymorphisms (MARTINELLI et al., 2016), to establish treatment plans for surgeries (HSIEH; DEDHIA; TOLLEFSON, 2018), to screen morphological alterations manifested in the oral cavity and the adjacent bones during life (SOUZA-SILVA et al., 2018), and to provide morphological information in forensic investigations (OETTER; DEMETER; L'ABBÉ, 2016;
WÄRMLÄNDER et al., 2019). However, the outcomes of predicting facial aging in practice depend on the available and applied methods. This study combined photoanthropometry and quadratic statistical modeling for the extraction and treatment of facial morphological data. The proposed methodological approach was able to describe the facial morphological alterations of female and male Brazilian subjects over the time.

The photoanthropometric approach used in the present study was founded on the projection of facial ratios based on the diameter of the iris. The stability of the 
iris enables a visualization of dynamics of the PAIs and their relative growth (MACHADO et al., 2017). Consequently, reliable ratios of the facial morphological structures were obtained. Recent studies in the field also addressed the diameter of the iris as a reference measurement for calculating ratios of the human face (MACHADO et al., 2017; BORGES et $a l ., 2018)$. In these studies, the human face was mapped with a considerably lower quantity of measurements $(n=10)$. Differently, the present study performed a deeper investigation of the morphology of the human face by analyzing the information from 208 measurements. In practice, the increase in the quantity of measurements allows a more detailed simulation of facial aging and a better understanding of growth dynamics.

An additional characteristic of the methods adopted in this study was the quality-control procedure established by comparing the performance of three different statistic models. The quadratic model reached better outcomes - with a mean coefficient of determination $\left(\mathrm{R}^{2}\right)$ of $52.14 \%( \pm 0.15)$ in females and $60.87 \%$ $( \pm 0.15)$ in males. This finding may be justified by the fact that quadratic models describe better the outcomes that are not linearly distributed, such as the allometric human facial growth. "Allometry" is the term used to explain the harmonious growth of the normal human face within the different developmental timing of each facial structure (MANDARIN-DE-LACERDA, 1993).
Once the statistical model with better performance was selected, human facial growth outcomes were separately obtained based on sex. Females and males showed a prevalence of $99.04 \%$ and $100 \%$ of PAIs statistically associated with age $(\mathrm{p}<0.05)$, respectively. With the diameter of the iris as a reliable fixed reference in the human face, the behavior of the remaining 207 PAIs was assessed. The PAIs with the most evident morphological alteration over the time were those related to the vertical growth of the human face, especially the ratios that involved distances from the gnathion landmark (in the chin region) to the glabella, the eyes and the midnasal landmarks. Similarly, studies in the past described the facial growth in a fourth degree polynomial equation and showed that the vertical height of the human face may be associated with the mandibular plane (e.g. growth of the anterior height of the human face influences the mandibular plane) (VAN DER BEEK, HOEKSMA; PRAHLANDERSEN, 1991). Despite the strong connection with a clinical application in Plastic and Maxillofacial Surgery, the outcomes obtained in the past and in the present are not properly comparable because in the past longitudinal analysis were performed by landmarking bone references. In the present study, facial soft tissues are also taken into account, especially because they play an important part in simulations of age progression.

The analyses based on sex revealed that growth in females manifests earlier than males (Table 4). Figure 4 shows that 
the height of the female face triggers a stronger development around the age of 11 , while in males the ascending curve is more evident around the age of 14. This outcome is in accordance with the consolidated scientific literature on pubertal growth spurt (SOLIMAN et al., 2014). Finally, it must be noted that growth is a quantifiable phenomenon that may be positive (increase in size) or negative (decrease in size) (MOSS, 1964). This study sampled a population of individuals that were in a young age range. Consequently, they may not express high negative values in growth as those expected in older ages (e.g. because of the decrease in muscular tissue). For this reason, specific PAIs do not show a descending (negative) curve in size.

In order to enable a better understanding of facial growth, ten PAIs ranked with the most evident alterations over the time were explored in table 5 . In this table, the cumulative growth rates of facial ratios were provided for females and males from 2 to 24 years of age. Additionally, the gradual growth within an interval of two years was also reported and distributed based on sex. However, it is important to highlight that because of the inherent limitations of statistical modeling facial growth data is treated and expressed as a continuous phenomenon even in the early adulthood. Figure 5 illustrates this limitation by showing non-realistic representations of the predicted facial growth in females and males around the age of 18 . More specifically, an overestimated growth of the lower third of the human face is manifested. In practice, these outcomes indicate that photoanthropometry combined with quadratic modeling may be used for understanding facial growth patterns in health sciences, but may not be accurately enough to support criminal investigations in the forensic sciences. A clear application of the technique and statistical modeling, however, is in the field of human growth and aging (GONZALES; MACHADO; MICHELCROSATO, 2020). Understanding how the morphology of the human face changes over time is important to improve the prediction of orthopedic and orthodontic treatment, the establish treatment plan for maxillofacial surgeries, the understand patient's decision for orofacial aesthetics and to support the treatment of pediatric patients on follow-up sessions for body growth. Additionally, when facial aging is analyzed from the perspective of body growth, several applications emerge especially those related to understanding the abnormal development of the human body. The present study depicted the normal growth curve of male and females faces from a large and standardized sample. Comparisons of patients' development with the present facial growth and aging pattern might be interesting to investigate if abnormal morphological changes are expected or not.

Future studies in the field should investigate different populations in order to enable the extrapolation of the present outcomes worldwide. Statistic 
approaches should include different data modeling, such as non-linear equations, to explore the behavior of the PAIs from a different perspective. Moreover, longitudinal studies are encouraged for a more realistic assessment of the development of the human face.

\section{Conclusion}

This study provided scientific evidence to support to use of photoanthropometric analysis and quadratic modeling to describe the dynamics of facial growth and aging from child- to adulthood. This approach can be used in studies dedicated to understand the growth and aging pattern of Brazilians. In particular, information of growth and aging is useful to enable optimal treatment plan, namely orthopedics, orthodontics, pediatrics, maxillofacial surgery and forensics. From a practical perspective, growth patterns of children and young adults could be compared to the pattern of facial growth and aging showed from the Brazilian faces sampled in this study.

\section{Acknowledgements}

The authors express their gratitude to the Technical and Scientific Section of the Brazilian Federal Police, especially to the Unit of Forensic Electronics and Multimedia of the National Institute of Criminalistics, as well as to Edmar Antônio da Silva, for the development of SAFF-2D ${ }^{\circledR}$ software package and FACISGroup (Forensic Craniofacial Identification Scientific Group - Brazil).
Funding: This work was supported by the Coordination for the Improvement of Higher Education Personnel - CAPES [funding number 0025/2014].

\section{A dinâmica do envelhecimento facial por meio de análise fotoantropométrica e modelagem quadrática da infância à fase adulta - um estudo multicêntrico}

\section{Resumo}

Este estudo objetivou analisar a dinâmica do envelhecimento facial por meio de fotografias de indivíduos em diferentes grupos etários a fim de se estabelecer um padrão da maturação facial. A amostra consistiu de fotografias digitais obtidas padronizadamente de 1273 brasileiros com idades entre 2 e 24 anos igualmente distribuídos por sexo em doze grupos $(2,4,6,8,10,12,14$, $16,18,20,22$ e 24 anos). O software SAFF-2D ${ }^{\circledR}$ (Sistema de Análise Facial Forense, Polícia Federal Brasileira, Brasil) foi utilizado para a marcação de 28 pontos de referências em cada imagem. Duzentas e oito medidas foram calculadas. Indicadores fotoantropométricos (IFA) da anatomia facial foram obtidos com base em uma referência fixa (diâmetro da íris). Os modelos estatísticos linear não transformado, quadrático e log-linear foram testados para investigar a melhor abordagem para descrever a dinâmica do envelhecimento facial em muIheres e homens. A modelagem quadrática atingiu os melhores resultados para muIheres $\left(R^{2}<73.2 \%\right.$, média: $\left.52.14 \% \pm 0.15\right)$ e homens $\left(\mathrm{R}^{2}<80.8 \%\right.$, média: $60.87 \% \pm$ 0.15). A maioria dos IFA ( $>99.04 \%$ ) foi estatisticamente associada com a idade em mulheres e homens $(p<0.05)$. Alterações faciais verticais foram as mais evidentes com o envelhecimento, em especial a al- 
tura da face $(p<0.05)$. A extração e tratamento de dados realizados neste estudo demonstraram que a fotoantropometria e a modelagem quadrática compuseram a melhor abordagem para descrever a dinâmica do crescimento facial envelhecido da infância à fase adulta.

Palavras-chave: Envelhecimento; Anatomia; Antropologia; Medicina Legal; Odontologia Legal.

\section{References}

BICALHO, G. C.; ALVES, M. C. A.; PORTO, L. F.; MACHADO, C. E. P.; VIDAL, F. de B. Solving the facial growth problem in the biometric face recognition using photo-anthropometric ratios by iris normalization. International Workshop on Biometrics and Forensics, Piscataway, v. 1, n. 1, p. 1-6, 2018. Doi: 10.1109/IWBF43282.2018

BISHARA, S. E. Facial and dental changes in adolescents and their clinical implications. Angle Orthodontist, Appleton, n. 70, n. 6, p. 471-483, 2000. Doi: 10.1043/0003-3219(2000)070<0471:FADCIA $>2.0 . \mathrm{CO} ; 2$

BORGES, D. L.; VIDAL, F. B.; FLORES, M. R. P.; MELANI, R. F. H.; GUIMARÃES, M. A.; MACHADO, C. E. Photoanthropometric face iridial proportions for age estimation: An investigation using features selected via a joint mutual information criterion. Forensic Science International, Lausanne, v. 284, n. 1, p. 9-14, 2018. Doi: 10.1016/j. forsciint.2017.12.011

CATTANEO, C.; OBERTOVÁ, Z.; RATNAYAKE, M.; MARASCIUOLO, L.; TUTKUVIENE, J.; POPPA, P.; GIBELLI, D.; GABRIEL, P.; RITZ-TIMME, S. Can facial proportions taken from images be of use for ageing in cases of suspected child pornography? A pilot study. International Journal of Legal Medicine, Heidelberg, v. 126, n. 1, p. 139-144, 2012. Doi: 10.1007/s00414-011-0564-7
CATTANEO, C.; RITZ-TIMME, S.; GABRIEL, P.; GIBELLI, D.; GIUDICI, E.; POPPA, P.; NOHRDEN, D.; ASSMANN, S.; SCHMITT, R.; GRANDI, M. The difficult issue of age assessment on pedo-pornographic material. Forensic Science International, Lausanne, v. 138, n. 1-3, p. 21-24, 2009. Doi: 10.1016/j.forsciint.2008.09.005

CHARMAN, S. D.; CAROL, R. N. Age-progressed images may harm recognition of missing children by increasing the number of plausible targets. Journal of Applied Research in Memory Cognition, Amsterdam, v. 1, n. 3, p. 171-178, 2012. Doi: 10.1016/j. jarmac.2012.07.008

DAVIS, J. P.; VALENTINE, T.; DAVIS, R. E. Computer assisted photo-anthropometric analyses of full-face and profile facial images. Forensic Science International, Lausanne, v. 200, n. 1-3, p. 165-176, 2010. Doi: 10.1016/j. forsciint.2010.04.012.

ENLOW, D. H. Facial Growth. Philadelphia: Saunders, 1990.

ERICKSON, W. B.; LAMPINEN, J. M.; FROWD, C. D.; MAHONEY, G. When age-progressed images are unreliable: The roles of external features and age range. Science \& Justice, Harrogate, v. 57, n. 2, p. 136-143, 2017. Doi: 10.1016/j.scijus.2016.11.006

FLORES, M. R. P.; MACHADO, C. E. P. Manual of facial photoanthropometry: landmarks in frontal view from visual references. Brasília: National Institute of Criminalistics, 2017.

FLORES, M. R. P.; MACHADO, C. E. P.; GALLIDABINO, M. D.; ARRUDA, G. H. M. DE; SILVA, R. H. A. DA; VIDAL, F. B. DE; MELANI, R. F. H. Comparative assessment of a novel photo-anthropometric landmarkpositioning approach for the analysis of facial structures on two-dimensional images. Journal of Forensic Sciences, Chicago, v. 64, n. 3, p. 828-838, 2019. Doi: 10.1111/15564029.13935 
GONZALES, P. S.; MACHADO, C. E. P.; MICHEL-CROSATO, E. Analysis of neoclassical facial canons for Brazilian white young adults and comparison with North American Caucasian population. The Journal of Craniofacial Surgery, Ontario, v. 31, n. 5, p. e432-e435, 2020. Doi: 10.1097/ SCS.0000000000006339

HSIEH, T. Y.; DEDHIA, R.; TOLLEFSON, T. T. Cleft rhinoplasty: Strategies for the multiply operated nose. Facial Plastic Surgery, New York, v. 34, n. 3, p. 290-297, 2018. Doi: 10.1055/s-0038-1653986

ISÇAN, M. Y.; HELMER, R. P. Forensic analysis of the skull. New York: Wiley-Liss, 1993.

KLEINBERG, K. F.; VANEZIS, P.; BURTON. A. M. Failure of anthropometry as a facial identification technique using high quality photographs. Journal of Forensic Sciences, Chicago, v. 52, n. 4, p. 779-783, 2007. Doi: 10.1111/j.1556-4029.2007.00458.x

KOUDELOVÁ, J.; DUPEJ. J.; BR $\square \square \mathrm{EK}$, J.; SEDLAK, P.; VELEMÍNSKÁ, J. Modeling of facial growth in Czech children based on longitudinal data: Age progression from 12 to 15 years using 3D surface models. Forensic Science International, Lausanne, v. 248 , n. 1, p. 33-40, 2015. Doi: 10.1016/j. forsciint.2014.12.005

LAMPINEN, J.; ARNAL, J. D.; ADAMS, J.; COURTNEY, K.; HICKS, J. L. Forensic age progression and the search for missing children. Psychology, Crime \& Law, Milton Park, v. 18, n. 4, p. 405-415, 2012. Doi: 10.1080/1068316X.2010.499873

LINDSAY, K. E.; RÜHLI, F. J.; DELEON, V. B. Revealing the face of an ancient Egyptian: synthesis of current and traditional approaches to evidence-based facial approximation. Anatomical Record, Hoboken, v. 298, n. 6, p. 1144-1161, 2015. Doi: 10.1002/ar.23146

MACHADO, C. E. P.; FLORES, M. R. P.; LIMA, L. N. C.; TINOCO, R. L. R.; FRANCO, A.; BEZERRA, A. C. B.; EVISON, M. P.;
GUIMARÃES, M. A. A new approach for the analysis of facial growth and age estimation: Iris ratio. PLoS One, San Francisco, v. 12, n. 1, p. e0180330-0180330, 2017. Doi: 10.1371/ journal.pone. 0180330

MANDARIN-DE-LACERDA, C. A.; URANIA-ALVES, M. Growth allometry of the human face: analysis of the osseous component of the mid and lower face of Brazilian fetuses. Annals of Anatomy, New York, v. 175, n. 5 , p.475-479, 1993. Doi: 10.1016/S09409602(11)80119-6

MARTINELLI, M.; GIRARDI, A.; CURA, F.; NOURI, N.; PINTO, V.; CARINCI, F.; MORSELLI, P. G.; SALEHI, M., SCAPOLI, L. Non-syndromic cleft lip with or without cleft palate in Asian populations: Association analysis on three gene polymorphisms of the folate pathway. Archives of Oral Biology, Oxford, v. 61, n. 1, p. 79-82, 2016. Doi: 10.1016/j. archoralbio.2015.10.019

MORETON, R.; MORLEY, J. Investigation into the use of photoanthropometry in facial image comparison. Forensic Science International, Lausanne, v. 212, n. 1-3, p. 231-237, 2011. Doi: 10.1016/j.forsciint.2011.06.023

MOREWITZ, S. J.; COLLS, C. S. Handbook of missing persons. Cham: Springer International Publishing, 2016.

MOSS, M.L. Vertical growth of the human face. American Journal of Orthodontics and Dentofacial Orthopedics, Amsterdam, v. 50, n. 5, p. 359-376, 1964. Doi: 10.1016/00029416(64)90176-9

OETTER, A. C.; DEMETER, F. P.; L'ABBÉ, E. N. Ancestral variations in the shape and size of the zygoma. Anatomical Record, Hoboken, v. 300, n. 1, p. 196-208, 2017. Doi: 10.1002/ar.23469.

RAFAI, N.; LEMOS, M.; KENNES, L. N.; HAWARI, A.; GERHARDT-SZÉP, S.; CLASSEN-LINKE, I. Anatomy meets dentistry! Linking anatomy and clinical practice in the preclinical dental curriculum. $B M C M e$ - 
dical Education, London, v. 16, n. 1, p. 305305, 2016. Doi: 10.1186/s12909-016-0825-8

RAT NAYAKE, M .; OBERTOVÁ, Z.; DOSE, M.; GABRIEL, P.; BRÖKER, H. M.; BRAUCKMANN, M.; BARKUS, A.; RIZGELIENE, R.; TUTKUVIENE, J.; RITZ-TIMME, S.; MARASCIUOLO, L.; GIBELLI, D.; CATTANEO, C. The juvenile face as a suitable age indicator in child pornography cases: a pilot study on the reliability of automated and visual estimation approaches. International Journal of Legal Medicine, Heidelberg, v. 128, n. 5, p. 803-808, 2014. Doi: 10.1007/s00414-013-0875-y

RICANEK, K.; BOONE, E. The effect of normal adult aging on standard PCA face recognition accuracy rates. IEEE International Joint Conference on Neural Networks, Piscataway, v. 1, n. 1, p. 2018-2023, 2005. Doi: 10.1109/IJCNN.2005.1556210

RIGHI, G.; PEISSIG, J. J.; TARR, M. J. Recognizing disguised faces. Visual Cognition, Milton Park, v. 20, n. 2, p. 143-169, 2012. Doi: 10.1080/13506285.2012.654624

SCANDRETT, C. M.; SOLOMON, C. J.; GIBSON, S. J. A person-specific, rigorous aging model of the human face. Pattern Recognition Letters, Amsterdam, v. 27, n. 15, p. 1776-1787, 2006. Doi: 10.1016/j.patrec.2006.02.007

SOLIMAN, A.; SANCTIS, V. DE; ELALAILY, R.; BEDAIR, S. Advances in pubertal growth and factors influencing it: Can we increase pubertal growth? Indian Journal of Endocrinology and Metabolism, Mumbai, v. 18, n. 1, p. s53-62, 2014. Doi: 10.4103/22308210.145075

SOUZA-SILVA, B. N.; VIEIRA, W. DE A.; BERNARDINO, Í. DE M.; BATISTA, M. J.; BITTENCOURT, M. A. V.; PARANHOS, L. R. Non-syndromic tooth agenesis patterns and their association with other dental anomalies: A retrospective study. Archives of Oral Biology, Oxford, v. 96, n. 1, p. 26-32, 2018. Doi: 10.1016/j.archoralbio.2018.08.014
TAYLOR, K. T. Forensic Art and Illustration. Boca Raton: CRC Press, 2000.

TEMPORINI, H. Child pornography and the internet. The Psychiatry Clinics of North America, Philadelphia, v. 35, n. 4, p. 821-835, 2012. Doi: 10.1016/j.psc.2012.08.004

TURK, M.; PENTLAND, A. Eigenfaces for recognition. Journal of Cognition Neurosciences, Cambridge, v. 3, n. 1, p. 71-86, 1991. Doi: 10.1162/jocn.1991.3.1.71

VALENTINE, T. Face-space models of face recognition. In: WENGER, M. J.; TOWNSEND, J. T. (Org.). Computational, geometric, and process perspectives on facial cognition - contexts and challenges. Hillsdale: Lawrence Erlbaum Associates, 2001. p. 83-113.

VAN DER BEEK, M. C. J.; HOEKSMA, J. B.; PRAHL-ANDERSEN, B. Vertical facial growth: a longitudinal study from 7 to 14 years of age. European Journal of Orthodontics, Oxford, v. 13, n. 3, p. 202-208, 1991. Doi: 10.1093/ejo/13.3.202.

VON ELM, E.; ALTMAN, D. G.; EGGER, M.; POCOCK, PETER, S. J.; GØTZSCHE, C.; VANDENBROUCKE, J. P. The strengthening the reporting of observational studies in epidemiology (STROBE) statement: guidelines for reporting observational studies. Journal of Clinical Epidemiology, Oxford, v. 61 , n. 4 , p. $344-349$, 2008. Doi: $10.1016 /$ j. jclinepi.2007.11.008.

WÄRMLÄNDER，S. K. T. S.; GARVIN, H.; GUYOMARC'H, P.; PETAROS, A.; SHOLTS, S. B. Landmark typology in applied morphometrics studies: what's the point? Anatomical Record, Hoboken, v. 302, n. 7, p. 1144-1153, 2019. Doi: 10.1002/ ar. 24005

WILKINSON C.; RYNN, C. Craniofacial identification. Cambridge: Cambridge University Press, 2012.

XU, C.; MAKIHARA, Y.; YAGI, Y.; LU, J. Gait-based age progression/regression: a baseline and performance evaluation by age 
group classification and cross-age gait identification. Machine Vision and Applications, New York, v. 30, n. 1, p. 629-644, 2019. Doi: 10.1007/s00138-019-01015-x

YANG, Y. Can the strengths of AIC and BIC be shared? A conflict between model identification and regression estimation. Biometrika, Oxford, v. 92, n. 4, p. 937-950, 2005.

ZENG, J.; MA, X.; ZHOU, K. Photo-realistic face age progression/regression using a single generative adversarial network. Neurocomputing, Amsterdam, v. 366, n. 13, p. 295-204., 2019. Doi: 10.1016/j.neucom.2019.07.085

Corresponding author
Laíse Nascimento Correia Lima
Departamento de Odontologia I
Universidade Federal do Maranhão, Brasil
Av. dos Portugueses, s/n - Bacanga
EP: 65.080-805, São Luís, MA, Brasil
Phone: + 55 61 98365-9890
E-mail: laiselima@msn.com

